\title{
RENDERING CAESAR: THOUGHTS ON THE TRANSLATION INTO ENGLISH OF N P VAN WYK LOUW'S GERMANICUS
}

\author{
J-M Claassen (Stellenbosch University)
}

\begin{abstract}
This paper discusses its author's attempt to translate into English the verse drama Germanicus by the Afrikaans poet NP Van Wyk Louw, which is based on Tacitus' Annales 1-3. After a general discussion of translation theory and of Louw's theories relating to the classical tradition, the paper highlights, with examples, problems encountered on the levels of prosody, of register and of equivalence of meaning. Louw's poetic Afrikaans is so concise that it requires an effort to be as brief in English. "Shakespearian English", both lexis and wordorder, is closer to the Germanic Afrikaans, but would be unacceptable in a modern translation. Louw's idiosyncratic use of Afrikaans, deliberate archaisms and occasional neologisms call for interpretative reading before these can be translated. The paper ends with a short reference to the place of Louw's Germanicus in the international Classical tradition.
\end{abstract}

\section{Background}

The dramatic structure of Tacitus' Annales has been the subject of considerable scholarly interest (Mendell 1935, Fabbrini 1986, Billerbeck 1991). The essentially dramatic structure of Annales 1-3 was exploited by the Afrikaans poet N. P. Van Wyk Louw in his Germanicus (1956). ${ }^{1}$ Louw turned Tacitus' narrative relating the role of Cnaeus Calpurnius Piso in the death of Germanicus into a cohesive play. The drama is a highlight in Afrikaans literature that deserves international attention. It also works as a radio play. Its interest lies in its amazing sweep of words and Louw's interpretative sense. Louw is at his best in the great monologues that dominate the various debates between the main protagonists. His non-standard Afrikaans has a grand eloquence that sweeps the reader or listener along in a torrent of denselyargued meaning. It was for these reasons that I have attempted to translate the drama into English. This paper deals with some of the constraints that faced the translator, and my answers to these challenges.

The drama was composed during the second World War, but first published in 1956, after parts had been published even earlier, and had also been produced on radio. Its first staging was in the Bellville Civic Centre in 1956. I saw this performance as a callow high school Latin student, then still totally unfamiliar with both Germanicus and Tacitus. What troubled me then (a powerful hero concerned with keeping "pure” but unwilling to do anything to retain his purity) is exactly what disturbs many modern readers of Tacitus. I next saw the play when I had gained considerably more experience of Roman history, at a performance by Stellenbosch students in 1971 or 1972. That production awakened my ambition to bring this great play to the attention of the larger Classical world. When at last I tackled it, thirty-two years later, I found the challenge exhilarating.

1 See Claassen 1996 for discussion and a more complete bibliography. Conradie 1974 discusses Louw's sources. 
Louw was a creative and imaginative poet. Germanicus deals with the corruption inherent in absolute power and the paradoxical powerlessness of the powerful to counter the forces that sweep him into despotic rule. Louw was clearly steeped in the Classics and continued reading Latin authors after attaining a BA at the University of Cape Town in 1925, majoring in Latin, German, and Afrikaans and Dutch (Steyn 1998:54). His continued interest in Latin literature is attested to also by the title of a later collection of poems ("Tristia" 1962, based on the name of Ovid's exilic work) published while he was in voluntary "exile", teaching in Amsterdam during the late forties and most of the fifties.

A critic like Dominik ${ }^{2}$ would like to read criticism of the South African Nationalist government (that had been in power for eight years when the drama was published) and dire warnings of its absolutism into Louw's drama. ${ }^{3}$ But in the light of the fact that Germanicus had been completed by December 1944 (Steyn:414), when the Nationalist government had not yet come into power, this cannot be. Louw himself admitted that certain passages were aimed at General Smuts, leader of the then dominant South African Party, whom many Afrikaners, still embittered by memories of the Anglo-Boer War, blamed for his so-called "pro-English" stance (id. 406). ${ }^{4}$ Van Vuuren (1988:73), writing two years before the sea-change that eventually overturned the old order in South Africa, speaks of Louw's later "moving away from hard nationalism", and points out (p. 75) that Louw's Tristia was "virtually mythologised in a hermetically sealed off world of literature". ${ }^{5}$ This stance Van Vuuren detected in 1988 as then still keeping Afrikaans intellectuals from contextualising any potentially explosive political writings of their time. That Louw's attitudes may have changed over time is, however, not the aim of my discussion. ${ }^{6}$

Yet if one accepts that an author of genius often reaches out in a wider sweep than he himself may be aware of, Louw's vatic portrayal of the dangers inherent in

2 He postulated this theory in a paper on “African drama,” that included discussion of Opperman’s Periandros van Korinthe, at a conference of the Classical Association of South Africa, Pietermaritzburg, in July 2005. For a theoretical overview of the influence of ideology in translation, see the rubric "Linguistic perspectives on translation" by Mona Baker in France 2000: 20-26, especially p. 23.

3 Van Rensburg 1990, discussing Louw as “symbolist”, reiterates the fact of Louw's essential nationalism, but contrasts it with Louw's equal adherence to the concept of individualism, comparing it with his simultaneous passion for the irrationality of intuition and for intellectual clarity.

4 Louw himself, in a lecture given at Stellenbosch in 1936, called for Afrikaans literature to rise above the parochial to treat of universal themes (Van Wyk 2004, translating Louw's own “Die rigting van die Afrikaanse Letterkunde,” 1939).

5 My translation of quotations from an Afrikaans article. The title of Louw's set of essays Lojale Verset (1939) can be translated as "Loyal Resistance”, but this resistance is literary, not political. Only one chapter (pp. 106-8) refers to matters political, but his concern is the inability, he notes in Afrikaners, to accept criticism. For Louw, “criticism is a nation’s conscience” (p. 108, my translation).

6 In a notoriously drawn-out polemic between Louw and Opperman, Louw himself famously decried the so-called “psychological”, or biographical, approach that would read an author's personal history or attitudes from his literary productions (Steyn 1998: 659-666, 688-693). 
absolute power can be taken to have reflected both the South Africa of his time and the world for all time. ${ }^{7}$

So Louw chose to propound a timeless human problem, the corruption inherent in absolute power, within a specific historical framework. Louw himself was very aware of the importance of the classical tradition, and on occasion quoted Dekker on literary influence being "not a physical mixture but a chemical process", that is, the elements of imitation are so intermixed that they create what is essentially something new (Schutte 1996). This is a very interesting view of the nature of intertextuality and its role in the creation of original works. Louw's use of Tacitus as source was not a mere rewriting of the historian's narrative in dramatic form, but a profound recasting of the classical text into a totally new format. The drama appears on the surface to follow the details of Tacitus' narrative almost exactly, but events recorded by Tacitus are conflated or elided, and scenes, even characters (Thusnelda, Marcus, Lucius, the doctor), are invented for the sake of the dramatic portrayal of the main protagonists.

Louw shows Piso as loyal to the republican ideal. This loyalty is initially shared by Louw's Germanicus. This agrees with the general critical interpretation of Tacitus' portrayal of the two men. Louw's portrayal helps to explain Tacitus' Piso as both defender of libertas, and tool in the hands of Tiberius. Their gradual disaffection is satisfactorily accounted for by Louw's interpretation of the two characters. Germanicus intellectualizes his disagreement with the excesses that imperial rule inevitably lead to, and he becomes more and more passive; Piso wants bluntly to return to the old Republican system and tries to urge Germanicus to action. Neither understands the other's point of view. Louw's Germanicus is an intellectual, whose own historical awareness leads to inactivity, even though he knows that this inactivity will lead directly to his death (he refuses to try to root out the forces working against him). Ironically, in the end it is Piso's inaction, when he passively looks on while his wife and Germanicus' physician administer the poison, that causes the prince's death.

In an earlier paper (1996:148) I argue that Louw's "greatest contribution to a rounded picture of the affair is his recreation of the tangled intrigues of Livia and Tiberius and his projection of a Plancina disaffected from her republican husband Piso at a much earlier stage than Tacitus allows for”.

In this paper I tried to show that Louw's historical sense may be read from his "consistent and satisfactory interpretative reading of the facts at Tacitus' disposal". That paper discussed the drama in the context of the Senatusconsultum de Pisone

\footnotetext{
Van Rensburg later (1996), discussing Louw’s popular essays on literary topics, typifies Louw’s love of didacticism as an "awareness that a text speaks to an individual, not an author to a nation”, and stresses Louw’s “integrity and reasonableness”. Earlier (1989) Van Rensburg, in a discussion of Louw's changing attitudes to statutory literary censorship, pointed out that, to Louw, the artist "not only records reality but can change it" (again my translations). This observation may perhaps also be applied to Louw's general attitude to the state in political matters, but the set-up of the drama nowhere spells out such an intention in the case of the penning of Germanicus. There is, for example, no introductory essay by the poet. A poem in Tristia, contemporary to the publication of the drama, is titled "Nuusberigte 1956" (news reports). It is a clear indication of some questioning at the time of the direction in which the then young Nationalist government was going (Van Vuuren 1988).
} 
patre which was found in Spain (ancient Baetica) during the eighties of the twentieth century. It showed that the exoneration of Plancina as spelled out in the Senatusconsultum is consistent with Louw's rendering, and concluded that, if Louw had had the Senatusconsultum before him at the time of his composition of Germanicus, it would not have led him to alter any part, or change any word, of the drama. It was these words of Louw's, arranged with great poetic sensibility, that I have attempted to translate into English.

\section{On theories of translation}

Translating a modern text in a still-spoken language into another spoken language is not so very different from translating ancient "dead" languages, the more common practice of Classicists the world over. The same issues of translation apply - literal versus “deep" meaning, word-for-word equivalence versus dynamic equivalence. Translating poetry is even more complex: should the exact metrical pattern be maintained, or another metre be found as suitable vehicle? Pope's rhyming heroic couplets made of Homer's Iliad something other than the original. Although Pope himself averred that he was striving to maintain the "Rapture and Fire" of the original, Troy became Pope's Troy, not Homer's, his Achilles or Agamemnon should be wearing powdered wigs, not primitive Greek armour. Another decision a translator must take relates to the measure of "strangeness" a translation may reflect: to what degree should one strive for the Afrikaans to shine through one's English (rather in the manner of Herman Charles Bosman's English narratives of simple Afrikaner life), or should one strive to make the translation stand on its own as an independent literary work?

There are many theories of translation, not all fully formulated, nor even realised, by their proponents and practitioners. Fashions in translation theory may also be traced. The sub-discipline now known as "translation studies" has as further refinement "translation criticism", which may be subdivided once again into two almost opposing types, the first having adequacy, that is, equivalence to the source text, as criterion. The other trend, which France (2000:7) terms "journalist[ic] criticism" is less concerned with literalness, and more with the fluency and naturalness of a translation.

In the broader field of translation theory, which can almost not be separated from its practice, there is at present some movement away from Eugene Nida's influential views on the "science of translation" of the sixties of the twentieth century, which allowed for either "formal equivalence" or "dynamic equivalence". Nida's preference was for the latter, which would acculturate a translated text into the context of the target language, in order to maintain efficiency of communication, and would elicit both comprehension of intent and equivalence of response. ${ }^{8}$

8 Eugene A Nida, Towards a science of translating with special reference to the principles and procedures involved in Bible translation, Leiden, 1964: 182, quoted by France 2000:5. 
France $(2000: 4,5)$ cites the French scholar Meschonnic as Nida's chief opponent. ${ }^{9}$ His concern was for the "dignity of translation" to be enhanced through a conscious distantiation between the original and the translation, a retention of a certain "foreignness" in the new text in the target language. Meschonnic's view seems at present to be gaining ground.

It was always a puzzle to me as a student why translation from English to Latin was termed "prose composition" by nineteenth century schoolmasters and their successors, until I realised that all translation, at it best, is exactly that: the composition of something new. I have spoken above of Louw's palpable awareness of the literary tradition. Louw himself emphasised that tradition has always been the literary norm, but in discussing originality, also in the reworking of traditional material, he differentiated between imitatio and aemulatio. ${ }^{10}$ In a poem titled "Ars poetica” from his Tristia (1962: 34-5), Louw seems to suggest that only ideas, not literary forms, may be emulated:

Uit die gevormde literatuur

Is nooit weer poësie te maak nie

Uit die ongevormde wél.
From well-formed literature

No-one can remake a poem as before

Only from the unformed. (my own translation)

The poem goes on to suggest that it is possible to vary a theme, but not to "play" with it, nor even to abuse it, nor to stand "in the shoes of the great ones of the past". ${ }^{11}$ It ends with the idea (p. 35) that we have an injunction to recreate "the creation of the god"12 in words, that are both "truth and sign" (waarheid en teken). For Louw, such words need to be imbedded in a "purity of form" that strips away all but the essentials (Van Wyk 2004:77-8). Schutte (1996:127) indicates that, to Louw, translation was an important element in the creation of a national literature, but that, for Louw, the question to ask of a work, whether a translation or an imitation, is not "Is it new?" but, "Is it good?" For Louw, that is the essence of originality. This is not very far from the ancients' concept of originality as lying chiefly in the creative re-use of matter taken from a predecessor. This approach is also akin to the "journalistic criticism" cited above as one of the methods of practising translation criticism.

Let us consider what Van Wyk Louw has done in this drama, in the light of his own view, sketched above, of the correct use of literary influences from the past,. His rendering of Tacitus' dramatic Latin narrative prose into an Afrikaans verse drama is not a "translation" in the usual sense. It is also a far cry from the prose - or verse - composition of Victorian schoolboys.

Louw embarked upon an act of supreme creativity involving two conscious acts of transmutation: first he had to plumb the full implications of Tacitus' concise

9 H. Meschonnic, Pour la poétique II, Paris 1973, quoted by France 2000:4. For an exhaustive bibliography on translation theory, see France 2000:114-123.

10 For an overview of the history of shifting opinions on the potential field of translation, see the rubric “The limits of translation” by Douglas Robinson, in France 2000:15-20.

11 With a great poet, there are always layers of untapped meaning, but the general gist seems clear.

12 Louw uses lower case here. "The god" may stand for the literary masters of the past, or for their inspiration. 
and sometimes cryptic Latin, and rethink these in his native tongue. It is probable that Louw actually consulted the original Latin texts for his creation of the drama, as he was fluent in Latin. ${ }^{13}$ He had read Annales 5 for his degree (Steyn 1998: 532 n. 58) and it is probable that he would have had the complete work to hand. He himself admitted in a radio interview that he had spent some time (apparently from November 1941 to February 1943) in preparatory research and intensive reading of various sources, "Tacitus, Suetonius and others" with whose works he had in any case long been familiar (id. 403-5). Then he had to re-visualise historiography into a poetic drama, with all the constraints that movement from a readerly to an essentially oral medium would entail, while bearing in mind a target audience that was not necessarily familiar with any aspects of Roman history. This was not mere translation, but re-creation in a new generic format, and in new words, that is, with new "truths and signs".

My translation represents a third leap of language. My aim was both to make the world of Classical scholarship aware of Louw's tour-de-force of metamorphosing historiography into drama, and to convey something of the beauty of Louw's mastery of language. My translation aimed to be no more than as-near-as-possibly faithful imitation. ${ }^{14}$ For this, I had to explore the intricate nuances of Louw's concise and sometimes cryptic Afrikaans, and rethink these in my mother tongue. Not only was I required to rethink his words, but I had to obey the constraints of Louw's metric pattern and, with that, face the problem of differences in prosody between Afrikaans and English verse forms.

Holman and Boase-Beier (1999:1-17), discussing literary translation, argue that constraint is precisely what leads to creativity in the practice of the translator's art, particularly in the translation of poetry. They define (p.14) the role of the translator as "[having] changed from that of a faithful reproducer to an inventive interventionist". This is the essence of translation as aemulatio, rather than imitatio, Louw's terms. What I tried to do, was perhaps closer to imitatio, but still working within constraints, still requiring inventiveness.

In a rubric on "Linguistic perspectives in translation" in France (2000: 25) Mona Baker discusses a so-called "third code" as lying between the source language and the target language. This code is one of the constraints that operate in translation. ${ }^{15}$ It seems to indicate a striving toward "normalization", or homogeneity of language, in translated works.

She postulates, as explanation for this tendency toward linguistic middle ground, an awareness in translators that their texts will meet other expectations than will original texts. This amounts to a mediocrity of language, which is precisely what

13 In a personal communication his son Peter told me (9 February 2007) that his father had on occasion on his travels in Italy chatted in Latin with a priest whom he met, as his Italian was inadequate for a proper conversation

14 Discussion of Aristotle's concept of mimesis (Poetics 1.1447a18-b29) might be appropriate, but that would make of this paper a different type of essay, and I leave the matter here with the remark that Quintilian's discussion of imitatio (Inst. 1.11.3 and 10.2.1) emphasised the importance of tradition, and its fluid, creative adaptation in Roman literature.

15 She is describing the use of computer searches in vast corpora of texts that serve to distinguish certain characteristics in translated texts. 
I sought to avoid in my translation. I want my readers to react to my text as they would have reacted to Louw's, had they been able to understand Afrikaans. This aim added to the constraints that, I think, challenged my creativity. What follows below is an exposition of the main types of problem, that is, the major constraints, with which I was faced, and my attempts to meet these creatively.

\section{Common Germanic words}

To translate irregular blank verse from a Germanic language into a related Germanicderived language that has strong overtones of its other, Romance, origins, brings problems on various levels. The fact that English and Afrikaans have so many Germanic characteristics in common was surprisingly problematic. Words deriving from the same root would naturally occur to the translator to express similar ideas, but these roots in some cases have undergone a semantic shift, so that exact equivalence of form does not result in exact equivalence of meaning. For example wit (white) I have rendered as "candid" with "senators" (p. 3), and as "pale" with "ranks" (p. 107). The emotional "feel" of the English word "mean" is not the same as the Afrikaans gemeen, for which on p.97 I used "vicious". Wild (wild) in: so klein, so wild (p. 34) is more exactly rendered by "scared", so tiny, so scared. On p. 36 "reckless" is the best translation for wild, but a few pages on (p. 39) the exact Germanic equivalent "more wild" works best for the Afrikaans wilder.

\section{Prosody and metre}

The term "prosody" refers to the manner in which a particular language fits into a set metrical pattern. It offered the most knotty problems. Although a five-beat metrical patterning can be followed in both English and Afrikaans, the nature of each language and the word-stress in each are such that words simply fit into such a metre in different ways. This is because the stress patterns even of etymologically related words differ in the two languages. The plurals of virtually similar words are formed differently. Afrikaans often adds an additional syllable (the schwa, "-e") for the plural, whereas the most common English plural signifier ("-s") does not change the length of a word, hence legioene vs. legions, gode vs. gods. I often added "filler" syllables, hierdie and daardie becoming this here, that there. Throughout I tried to maintain Louw's metric pattern of stressed syllables ("beats"), as in: O gode, hou hul daar! (p. 2), that becomes: Ye gods, pray keep them there! and Is dit teater hier? Moet ons applous gee? (p. 3), became: Is this a theatre? And do you want applause?

One can maintain metrical pattern, even where prosody differs. Peter Green does that when translating Juvenal or Ovid's hexameters from Latin to English. Louw largely keeps to a five-beat verse pattern, such as: miskien 'n kern, klein, byna onsigbaar (p. 93), which I made: perhaps a kernel, small nearly invisible. ${ }^{16}$ The number of unstressed syllables may vary greatly and does not, in fact, affect the lilt of the verse. Occasionally his lines are shortened to four or even three beats, as in the

16 It was impossible here to reproduce or imitate the alliteration on $k$-, and I chose to ignore it. Elsewhere I managed to reproduce alliteration fairly faithfully. 
example, O gode, hou hul daar! or What d'you hear around the fires? for Wat hoor jy by die vure? (p. 1) So prosodic problems were solved by inserting more (sometimes fewer) unstressed syllables in a loose approximation of the metric feel of the original, but keeping to the same number of stressed syllables per line. Six beats work equally well: That's all that great Rome will offer you, old greybeard for Dis àl wat die groot Ryk jou gee, ou gryskop (p. 1).

\section{Density of Louw's poetry}

Louw's poetic Afrikaans is so concise that the common wisdom of translators, that it takes more words so say something in Afrikaans than in English, seldom applies. ${ }^{17}$ This naturally requires a condensation of the English that gives a very satisfactory poetic density, but can sometimes sound forced. The following example is from p.39:

sy vlote is gebreek teen vreemde strande en duine, teen somber kape uitgespoel waar voëls draai wat geen mens ken, neste maak

van stink doodsbeendere, en nagtelik skree

- ek hoor hul in my kop nog - bo die skuim

en die wit rots van Brittanje, die geheime;

ná elke trugslag kom hy heersender: dit moet 'n god wees wat hom gryp en lei! his fleets lay broken on those foreign strands and dunes, washed up on sombre capes watched over by birds that no man knows, nesting yet

on dead men's reeking bones, and nightly screeching I hear them shrilling in my head above the foam and the white rock of Britain, that secret place; above each downfall he rises stronger: for sure a god raised him and leads him still!

Occasionally, however, the Afrikaans is considerably longer than its English equivalent. "Filler words" are needed, as in Ek is geen koning van die konings nie-: I'm not a king of kings at all (p. 75). More difficult was the concise thought-pattern but more diffuse wording of Die kruisdood is verskriklik; en dis mense (p. 80, literally: "the cross-death is terrible, and it's people”). Expansion, for both metre and sense, brought: The cross is dreadful; and people suffer so.

\section{Word order, sentence structure and punctuation}

Using an exactly equivalent ("Germanic") word order in sentence structures would in most cases have resulted in understandable English, but would have sounded vaguely "Shakespearean". English syntax has over the centuries moved away from its

17 Density can be achieved by various means. In the passage quoted, there is an almost total dearth of "grammatical items" such as articles and prepositions, in favour of highly charged "content words" or "lexical items" (terms from the discipline of linguistics). 
Germanic origins. The dense and staccato four-syllabic So sterf ek nie! ("So die I not!”) became the more natural-sounding six-syllabic I will not die like that! It still has a three-beat prosody, but is now an iambic line. Five-syllabic Ken ek hulle nie! works better as the five-syllabic Don't I just know 'em! rather than its four-syllabic "Germanic" equivalent Know I them not! Occasionally an exact overlap of word order, meaning and prosody gives happy relief to the translator. The rather prosaic Maar wat hy sê, is waar (p. 3) works on all levels as But what he says, is true.

Louw's idiosyncratic punctuation mostly worked. He sometimes uses upper case where Afrikaans convention prescribes lower case. Thusnelda and the Nabatean king address Germanicus as " $U$ " ("You"). I have chosen to ignore this, but have retained his capital after a dash, as on p. 91, where a three-line interpolation is indicated with dashes and the next line begins a contrasting thought with upper case Maar ("But”). I retained Louw's lower case where sentences seem to run on in spite of pauses in meaning, as on p. 3:

It's twenty winters

that I have borne like this until the winter

came and sat upon my head: just see my hands -

gnarled roots; and see my back - it's been tanned with blows.

\section{Louw's idiosyncratic vocabulary}

Louw's idiosyncratic use of words, deliberate archaisms and occasional neologisms call for interpretative reading. For example Louw's trugslag (in the passage quoted at 5 above, $7^{\text {th }}$ line), for normal terugslag, became "downfall", and in the same line heersender (literally "ruling-er") "stronger”. The emphatic reduplicative superlative in van die aller- aller- allerfynstes (p. 73, "thrice-exceedingly fine people") became of the high, and higher, highest ranks. The unusual pylerig ("arrow-ish", p. 92) had to be expanded into bristling with darts. An idiosyncratic use of kram ("staple", which is by definition shaped like a hoop) in moet kram-wees (p. 73) translates into arcs across. Louw's Jy sukkel met die $a-b$-jab (p. 73) uses an almost totally unfamiliar old Germanic term, jab. I varied the familiar $a-b-c$, to You struggle with the $a-b-z$. which works, whether we say British "zed” or American "zee”.

\section{A variety of registers}

Louw's characters speak in a variety of registers. A particular word-order is idiomatic in a certain non-standard Afrikaans, for example Blaas òp die vuur, occurring twice on page one. $O p$ can be either a preposition ("on”) or an adverb ("up"). Stress on ò makes it an adverb. Standard Afrikaans word order puts it at the end of the sentence: Blaas die vuur op, but this has far less emotional impact.

The soldiers are cold and angry and they are stoking the fires of rebellion. I chose to interpret the first òp as a preposition: the first soldier merely asks his mate to "blow on the fire to make it flame up". When the more rebellious third soldier repeats it, adding blaas goed!, I translated less literally, implying rebellion. The extended line became: Stir up the embers, stir up well! 
The vernacular kjent for kind (child) in the mouth of an old soldier was impossible to duplicate idiomatically. The verse reads: Sò praat 'n kjent van groot Agrippa net (p. 14, something like: "So speaks a chee-ild of great Agrippa just". I toyed with: Thus speaks a child from great Agrippa's loins, but the register was wrong. It finally became: This is a child that great Agrippa's bred!

\section{Rhetorical and poetic devices}

Louw's use of zeugma was easier to translate. In the first scene our rebellious third soldier avers that the double-dealing Senate at Rome speaks in two languages. A fourth soldier answers him: En jy praat drie: Latyn, en groot, en sot (p.3). This becomes And you talk three: Latin, and big and rot.

Poetic devices were a wonderful challenge. The alliterative onomatopoeia in Dis vreemde pap wat in die potte prut (p. 1) was easily rendered as: It's a strange porridge a-plopping in the pots. Emphatic stress Hom laat jy staan! (also p. 1) translates into: Him you mustn't touch! More difficult was the linked word play in: Want "sien" is nie begryp, nie "gryp", verstaan nie. My word-chain links the three abstract nouns differently, but I felt that the spirit of Louw's idiom was being respected: For "see" is not foresee, not "grasp", not understand.

Perhaps the most difficult are idiomatic expressions that make no sense when rendered literally, as in the following long example (p. 3):

Hy’s nog nie moeg van klaas-wees!

Elke dag

wil hy nog die sersant se rottang vreet, vyf oulap - en sy klere, wapens, tent

en vroumensvleis daarmee betaal. Ons nie!
He's not yet tired of being Claus.

Every day he wants to guzzle the sergeant's

Malacca cane

five old rags - and his clothes, weapons, tent and womanfolk's meat pay with that. We not!

Klaas (German Claus), an abbreviation for Nicholas, is a labourer, as opposed to baas, "boss". An oulap, meaning "penny", is the Afrikaans equivalent of the Latin pannus , "a rag" (from which the word penny is derived), and a rottang is literally a cane, but in English it is associated with schoolboys or dandies, not soldiers. Vroumensvleis is a vulgarism for a prostitute. A literal translation would make no sense at all, hence my:

He's not yet sick of daily kicks and blows.

He still goes sucking at the sergeant's whip,

Five cents or so - and then his clothes and weapons, tent and juicy tarts are paid. But that's not us!

The very next line translates easily, and virtually word for word, both idiom and word rhythms coinciding neatly: Is ons nie van die trots ou heersersras? becomes Are we not of a proud old ruling race?. 
Diminutives are as frequent in Afrikaans as in Latin, and often denote appreciation or contempt. English expresses these feelings differently, hence my first two examples. Occasionally "small" will do, hence small white frogs for: wit paddatjies. Diminutives of adverbs are almost untranslatable. "fyntjies" (= "smally fine”) occurs twice on pp. 7-8. I give one example:

Sal die Ryk

van wit hand tot wit hand

fyntjies gegee word

in die senaat, soos 'n klein

dobbelsteen?
Will the empire

pass from one white hand

delicately to the next

in the senate, like half a pair

of dice?

The phrase half a pair of dice is an extreme example of the kind of latitude I occasionally allowed myself. The phrase serves as the semantic and metrical equivalent of klein dobbelsteen ("small gambling stone”), which is Louw's own idiosyncratic rendering of the more common diminutive, dobbelsteentjie ("a die"). Metrics required the line to be filled with "empty" syllables. Modern English vernacular usage prefers the plural "dice", even when only one "die" is meant. My compromise tries to accommodate all these disparate issues.

Most difficult were cases where the Afrikaans is ambiguous: die rotsige Petra wat geen Caesars ken (p. 91) can mean either that the Nabatean city knows no Caesars or that the Caesars do not know the city. Three lines later we find the key. The king of the Nabateans wants Germanicus to describe his city to Tiberius, hence the first line should be rendered: the rugged Petra that no Caesars have seen.

\section{Conclusion}

These, then, were some of the constraints around or through which I had to work. I experienced the truth of the aphorism that constraint leads to creativity, whether in an original work or in a translation. I certainly found the exercise of translation challenging, even exhilarating. I have seldom felt so disappointed when reaching the end of a self-imposed task as when I started on the last scene. Throughout Louw's reworking of Tacitus' story-line, his colouring of the basic history of Germanicus Caesar was easily transposed. The challenge lay in rendering Louw's words into English. I hoped in some measure to succeed in letting the richness and subtlety of Louw's Afrikaans interpretation of a Latin work of genius shine through.

The translation has not yet been widely disseminated, but I was fortunate to gain the comments of Professor Robert Reece-Evans of Harvard, conveyed to me by a friend. His comments seem to relate more to Van Wyk Louw's original conceptualization than to the words of my translation, a fact which I interpret as proof that my aim of accessibility of the original to an international readership has been achieved. Reece-Evans comments as follows:

I have gulped down Germanicus at one sitting. It is Racine-like; akin to his Brittannicus, which I once attended at the Odeon in Paris. Perilously humourless, hence the Irish injunction — " "play the comedy and let the tragedy 
take care of itself" - cannot apply. Power is all; gravitas! But it is the stuff of drama, the essence of which is conflict. There is missing from Germanicus himself — in the Piso scene at the end? - a protracted cry, explaining his own inner conflict. His crucifixion-speech, if you will, in which he justifies his passivity. But the play entire is very spare and coherent. I liked it very much, and learned from it. Caesarian paralysis? I think so. A crisis of confidence, the failure of nerve (Gilbert Murray). Livia versus Piso, in the end. Both Tiberius and Germanicus are pawns in the higher game for power. (Plancina's role is a deft touch). The importance of Piso is vastly appreciated for once, contra the Robert Graves caricature. Ah, the Germanic frontier!

Please to pass this on to the author, for what it is worth? The structure Germany, Rome, the East - is very beautiful.

As the author is no longer living, I cannot pass these comments on to him, but offer them to his wider South African readership, with the hope that other readers in the rest of the English-speaking world will react similarly, once the translation is published.

\section{BIBLIOGRAPHY}

Billerbeck, M 1991. Die Dramatische Kunst des Tacitus. ANRW II.33/4, 2752-2771.

Boase-Beier, J \& Holman, M 1999. The practices of literary translation: constraints and creativity. Manchester: St. Jerome Publishing.

Claassen, J M 1996. Germanicus revisited - and revised? Akroterion 41 133-150.

Conradie, P J 1974. Die gebruik van antieke bronne in Van Wyk Louw se Germanicus. In Conradie P J 1974, Spanning en ewewig. Pretoria: Academica.

Eck, W 1993. Das s.c. de Cn. Pisone Patre und seine Publication in der Baetica. Cahiers du Centre Glotz 4, 189-208.

Fabbrini, F 1986. Tacito tra storiografia e tragedia. In I raconti di Clio. Tecniche narrative della storiografia, coll. La Porta di Corno 6. Pisa.

France, $\mathrm{P}$ 2000. The Oxford guide to literature in English translation. Oxford: OUP.

Louw, N P Van Wyk 1962. Tristia en ander verse: Voorspele en vlugte 1950-1959. Cape Town: Human \& Rousseau.

Louw, N P Van Wyk 1939, $5^{\text {th }}$ repr. 1975. Lojale verset: Kritiese gedagtes oor ons Afrikaanse kultuurstrewe en ons literêre beweging. Cape Town: Tafelberg.

Louw, N P Van Wyk 1956, repr. 1972. Germanicus. Cape Town: Tafelberg.

Mendell, C W 1935. Dramatic construction of Tacitus’ Annals. Yale Classical Studies 5,3-53.

Schutte, H J 1996. Oorspronklikheid en verwante begrippe by N P van Wyk Louw. Literator 17 (1) 113-132.

Steyn, J C 1998. Van Wyk Louw: 'n lewensverhaal. Cape Town: Tafelberg, Vols. $1 \& 2$.

Van Rensburg, F J J 1990. Van Wyk Louw simbolis? Literator 11.1, 35-55.

Van Rensburg, F J J 1996. Hoe praat jy met 'n hele volk? Literator 17.1, 57-76. 
Van Rensburg, F J J 1989. Van Wyk Louw en sensuur. Literator 10.2, 30-44.

Van Vuuren, H 1988. Tristia in historiese konteks. Literator 9 (2):67-83.

Van Wyk, J Trans. 2004. Direction in Afrikaans literature by N P van Wyk Louw. Alternation 11.1, 71-78. 